\title{
A study on factors affecting buying of cosmetic products with reference to males in Ghaziabad
}

\author{
Dr Puja Roshani \\ Assistant Professor, KIET Group of Institutions, \\ Ghaziabad, India,pujasomdeo@gmail.com
}

\author{
Dr Deeksha Dwivedi \\ Corporate Recruiter, \\ Leslie's, USA
}

\begin{abstract}
The focus of this research is to identify the determinants that affect men purchasing behaviour when it comes to cosmetics. The research took place in Ghaziabad, Uttar Pradesh. The data was collected from 105 respondents using a survey method. The economy of the country is reliant on the possibility of personal care, which is also seen as an important aspect of the economy. The cosmetics business is one of the country's burgeoning industries. The Indian buyer's purchasing power and disposable income have increased dramatically; it has also developed a speciality for pushing associations in this field in the last decade, resulting in remarkable progress.

Index Terms-Male customers, Buying behaviour, Cosmetic products, Personal care.
\end{abstract}

\section{InTRODUCTION}

$\mathrm{T}$ HE ACCOMPLISHMENT of any business associations is reliant on understanding the conduct of buyers. Advertising individuals are constantly investigating the purchasing conduct and buying choices of consumers to foresee the future patterns and also investigate regarding how, when, what and why individuals purchase. As indicated by Global Cosmetic Industry report the brands providing proper instruction about how the products can be used with clear information about ingredients put in the products have made consumers use and spend more on these cosmetic products. Consumer behaviour can be comprehended as: "The study of decisions which a customer takes in order to satisfy its needs and wants".

\section{A. Indian Cosmetic Industry}

In the current context, it is being observed that the Indian cosmetics goods sector is blossoming into a full-fledged industry with impressive product and marketing development. Indian clients are shifting away from 'simply utilitarian' cosmetics and toward more developed 'and focused' restorative items. In 2011, Indian buyers spent just over US\$3 on makeup on an annual basis. In terms of cosmetics use, India has increased from $27 \%$ in 2005 to $31 \%$ in 2014 , and this trend is likely to continue in the next few years. Due to the entry of numerous multinationals into the Indian beauty care market starting in 2011, India has become a vibrant and extremely challenging market for cosmetics products. Foreign corporations are focused more on creative items, re- launching brands, and brand extensions across a range of price ranges. These businesses also offer a wide range of distribution channels to help them gain a foothold in the market. These businesses are implementing effective cost-cutting strategies in their advertisements, allowing them to pass on the enhanced value to their clients by rethinking their overall price approach. The increased awareness and beauty consciousness youth with financial independence has increased the demand of cosmetics products. In rural India due to less awareness and financial inability the growth of cosmetics markets is negligible. The increased competition and increased prices also contribute towards it.

\section{Literature Review}

The Indian beauty and fashion industry has been growing immensely due to development of new scientific techniques, new and innovative products and media hype. Due to increased awareness and increased disposable income along with changing demographic variables and lifestyle of the people the cosmetic industry is flourishing worldwide. According to Euromonitor International, (2006) [1] due to increased awareness and increased disposable income along with changing demographic variables and lifestyle of the people the cosmetic industry is flourishing worldwide.

Interestingly, I noticed that Indian buyers are focusing more on international products embarking on sophistication and increased social status although the scenario is different worldwide. People across different countries are switching to herbal and ayurvedic products [2].

It was observed that income levels of consumers and different brand dimensions like social, culture etc influence the buying behaviour of consumers. But there was no evidence regarding personal and psychological factors of consumers affecting their buying behaviour. [3]

It was found that consumer buying behaviour towards FMCG products, is affected by price, place, promotion and product quality the 4 P's of marketing. [4]

It was found out that the majority of the men believed that using men's cosmetics products improved their appearance and also helped them succeed in their career. [5]

It was identified that consumer buying decisions are influenced mainly by the five factors, which are quality product; product price; brand name; product packaging and advertising. [6]

It was identified that male consumers like to buy the cosmetics products independently. The males' focuses mainly on quality while buying the products. It was also found in the study that male customers prefer buying all their cosmetics products from one single shop of their convenience and choice. [7]

The customer purchasing practices steps in the decision process model. 
There are mainly five phases of customer buying behaviour

1. Issues/Need Recognition

2. Information search

3. Assessment of substitutes

4. Buying choice

5. Post buying behaviour

\section{Proposed Work}

\section{A. Need for Research}

This research was done with an intention to provide the cosmetics industry an insight about how the male customers decide to purchase the cosmetics products from a diversified range. And also helps in understanding the ranges of products of different brands which they prefer to buy.

\section{B. Objectives of the study}

1) To study the demographic profile of male buying cosmetics products.

2) To identify factors affecting males for buying cosmetics products.

3) To examine the reasons for buying cosmetic products.

4) To find out the types of cosmetics products bought by male consumers.

\section{Scope of the Study}

The study examines the buying behaviour of cosmetic products by male belonging to different segments in Ghaziabad City. The significant factors chosen for the investigation are as per the following:

\section{Demographic Profile of Male Consumers}

Age, Occupation and Monthly Income.

Major Factors identified for detailed study includes Buying behaviour, Reasons of purchase, Nature and types of products, Factors in purchase decision, Frequency of purchase, Spending Pattern, Collection of product information Influence of celebrity endorsement and Time duration.

Research Design - Descriptive Research Sampling Method-Non-Probability Convenience Sampling

Sampling Area -Ghaziabad Sampling Size- 105

\section{Methods of Data Collection}

Primary Data- Data was collected through questionnaires by mailing the respondents.

Secondary Data- Data was collected from various sources like research articles, books, internet and magazines etc.

\section{E. Method of Data Analysis}

For data analysis Ms excel 2010 has been used.

TABLE 1: Age

\begin{tabular}{|l|l|l|}
\hline $15-20$ Years & 9 & $8.6 \%$ \\
\hline $20-25$ Years & 64 & $61.9 \%$ \\
\hline $25-30$ Years & 11 & $11.4 \%$ \\
\hline $30-35$ Years & 11 & $11.4 \%$ \\
\hline $35-40$ Years & 10 & $6.7 \%$ \\
\hline Total & 105 & $100 \%$ \\
\hline
\end{tabular}

\section{Result \& Discussions}

Tabulation and Data Analysis. The Male Customers Demographic Details are mentioned in the tables below.

TABLE 2: OCCUPATION

\begin{tabular}{|l|l|l|}
\hline Self Employed & 9 & $8.6 \%$ \\
\hline Private Employees & 32 & $30.5 \%$ \\
\hline Student & 60 & $57.1 \%$ \\
\hline Business & 4 & $3.8 \%$ \\
\hline Total & 105 & $100 \%$ \\
\hline
\end{tabular}

Table 3: Monthly Income

\begin{tabular}{|l|l|l|}
\hline None & 56 & $53.3 \%$ \\
\hline Less than 10,000 & 4 & $3.8 \%$ \\
\hline $10,000-30,0000$ & 21 & $20 \%$ \\
\hline $30,000-50,000$ & 7 & $6.7 \%$ \\
\hline Above 50,000 & 17 & $16.2 \%$ \\
\hline Total & 105 & $100 \%$ \\
\hline
\end{tabular}

Table 4: Factors Affecting Male Buying Cosmetic Products Buying Behaviour

\begin{tabular}{|l|l|l|}
\hline Rarely & 20 & $19 \%$ \\
\hline Very Rarely & 28 & $26.7 \%$ \\
\hline Occasionally & 34 & $32.4 \%$ \\
\hline Frequently & 15 & $14.3 \%$ \\
\hline Always & 8 & $7.6 \%$ \\
\hline Total & 105 & $100 \%$ \\
\hline
\end{tabular}

Table 5: Reasons of Purchase

\begin{tabular}{|l|l|l|}
\hline Self Esteem & 9 & $8.6 \%$ \\
\hline Attractiveness & 5 & $4.7 \%$ \\
\hline Personal Care & 86 & $81.9 \%$ \\
\hline Celebrity Endorsements & 5 & $4.7 \%$ \\
\hline Total & 105 & $100 \%$ \\
\hline
\end{tabular}

TABle 6: Nature of PRODUCtS

\begin{tabular}{|l|c|c|}
\hline Chemical & 16 & $15.2 \%$ \\
\hline Herbal & 47 & $44.7 \%$ \\
\hline Semi-herbal & 17 & $16.2 \%$ \\
\hline Ayurveda & 25 & $23.9 \%$ \\
\hline Total & 105 & $100 \%$ \\
\hline
\end{tabular}

TABLE 7: Types OF PRODUCTS

\begin{tabular}{|l|l|l|}
\hline Skin Care & 52 & 49.5 \\
\hline Hair Care & 27 & 25.7 \\
\hline Body care & 26 & $24.8 \%$ \\
\hline Total & 105 & 100 \\
\hline
\end{tabular}


TABLE 8: FACTORS IN PURChASE DECISION

\begin{tabular}{|l|l|l|}
\hline Quality & 11 & $10.5 \%$ \\
\hline Price & 7 & $6.6 \%$ \\
\hline Brand & 50 & $47.6 \%$ \\
\hline Advertisements & 2 & $1.9 \%$ \\
\hline Features & 35 & $33.4 \%$ \\
\hline Total & 105 & 100 \\
\hline
\end{tabular}

Table 9: Frequency of Purchase

\begin{tabular}{|l|l|l|}
\hline Weekly & 9 & $8.6 \%$ \\
\hline Monthly & 60 & $57.1 \%$ \\
\hline Fortnightly & 12 & $11.4 \%$ \\
\hline Half Yearly & 15 & $14.3 \%$ \\
\hline Yearly & 9 & $8.6 \%$ \\
\hline Total & 105 & 100 \\
\hline
\end{tabular}

Table 10: Spending Pattern

\begin{tabular}{|l|l|l|}
\hline Below 500 & 67 & $63.8 \%$ \\
\hline $500-1000$ & 23 & $21.9 \%$ \\
\hline $1000-1500$ & 10 & $9.6 \%$ \\
\hline $1500-2000$ & 5 & $4.7 \%$ \\
\hline Total & 105 & $100 \%$ \\
\hline
\end{tabular}

Table 11: Collection of Product information

\begin{tabular}{|l|l|l|}
\hline Very rarely & 11 & $10.5 \%$ \\
\hline Rarely & 30 “' & $28.6 \%$ \\
\hline Occasionally & 20 & $21 \%$ \\
\hline Frequently & 14 & $13.3 \%$ \\
\hline Always & 28 & $26.7 \%$ \\
\hline Total & 105 & $100 \%$ \\
\hline
\end{tabular}

TABle 12: Influence of CELEBRity ENDORSEMENT

\begin{tabular}{|l|l|l|}
\hline Very rarely & 45 & $42.9 \%$ \\
\hline Rarely & 30 & $29.5 \%$ \\
\hline Occasionally & 15 & $15.2 \%$ \\
\hline Frequently & 8 & $4.8 \%$ \\
\hline Always & 7 & $7.6 \%$ \\
\hline Total & 105 & $100 \%$ \\
\hline
\end{tabular}

Table 13: Time Duration

\begin{tabular}{|l|l|l|}
\hline Less than 6 months & 17 & $16.2 \%$ \\
\hline $1-5$ Years & 39 & $37.1 \%$ \\
\hline $5-10$ Years & 24 & $22.9 \%$ \\
\hline $10-20$ Years & 13 & $12.4 \%$ \\
\hline Above 20 Years & 12 & $11.4 \%$ \\
\hline Total & 105 & $100 \%$ \\
\hline
\end{tabular}

\section{FINDINGS}

The majority of the respondents purchasing cosmetic products belonged to the age group of 20-25 years. The respondents were not having any monthly income due to the fact that the majority of the respondents were students.

Majority of the respondents bought cosmetic products for their personal care focusing more on skin related products. The respondents invested more on herbal products and considered brand as the most influencing factor for buying the products. The majority of the respondents spent less than Rs 500 in buying cosmetics products due the fact that the maximum respondents were students. More of the buyers collected prior information before buying any cosmetic products and did not consider celebrity endorsements for purchase. The majority of respondents were using cosmetics products between 1-5 years maybe due to the fact that the majority of the respondents were in the age group of 20-25 years and have reached adolescence stage.

\section{Conclusion \& Future Work}

Due to changing demographics and lifestyle scenarios men are becoming more conscious about their looks and appearance. In this research, it was found that men use more skin care products.

The younger generation is especially more inclined towards buying cosmetic products when compared to older generations. Monetary factor also plays an important role in buying behaviour of cosmetics products, people who earn more money can access these kinds of products more than those who are deficient in them. Many factors contribute towards men buying skin care products but the two most noteworthy ones are improvement in skin and personal cleanliness. The main reasons behind men buying cosmetics products indicate that men are concentrating more on their appearance off late.

\section{REFERENCES}

[1] https://www.euromonitor.com/article/global-cosmetics-and-toiletriessales-reach-five-year-high-in-2006 Global cosmetics and toiletries sales reach five year high in 2006 - Euromonitor.com

[2] C. Briney, "State of the industry," Global Cosmetic Industry, vol. 172, p. $26,2004$.

[3] J. S. L. \&. T. Z. Stávková, "Factors influencing consumer behaviour," Zemedelska Ekonomika-Praha, vol. 54, no. 6, p. 276, 2008.

[4] A. K. T. \&. P. V. Vibhuti, " A case study on consumer buying behavior towards selected FMCG products," International journal of scientific research and management, vol. 2, no. 8, pp. 1168-1182, 2014.

[5] A. Y. Khan, E. Karim and O. Abbas, "Identifying the Factors aIdentifying the Factors affecting the customer's Buying Behaviorffecting the customer's Buying Behavior," Identifying the Factors affecting the customer's Buying Behavior, pp. 147-156, 2016.

[6] S. S. Anjana, "A study on factors influencing cosmetic buying behavior of consumers.," International Journal of Pure and Applied Mathematics, vol. 118, no. 9, pp. 453-459, 2018.

[7] A. H. Kumar and John, S. F., \& Senith, S., "A study on factors influencing consumer buying behavior in cosmetic products.," International Journal of Scientific and Research Publications, vol. 4, no. 9, pp. 1-6, 2014. 